\title{
Oak regeneration at the arid boundary of the temperate deciduous forest biome: insights from a seeding and watering experiment
}

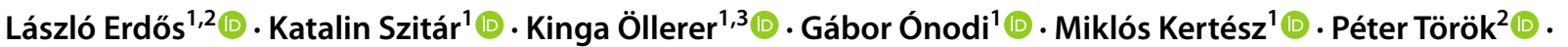 \\ Kornél Baráth $^{4} \cdot$ Csaba Tölgyesi $^{5}$ (1) $\cdot$ Zoltán Bátori $^{5}{ }^{(1)} \cdot$ László Somay $^{1} \cdot$ Ildikó Orbán $^{6}$ (i) György Kröel-Dulay ${ }^{1}$
}

Received: 14 August 2020 / Revised: 26 November 2020 / Accepted: 4 December 2020 / Published online: 23 January 2021

(c) The Author(s) 2021

\begin{abstract}
Previous studies found that pedunculate oak, one of the most widespread and abundant species in European deciduous forests, regenerates in open habitats and forest edges, but not in closed forest interiors. However, these observations usually come from the core areas of the biome, and much less is known about such processes at its arid boundary, where limiting factors may be different. In a full factorial field experiment, we tested the effects of different habitats (grassland, forest edge, forest interior) and increased growing season precipitation on the early regeneration of pedunculate oak in a forest-steppe ecosystem in Central Hungary, at the arid boundary of temperate deciduous forests. In the grassland habitat, seedling emergence was very low, and no seedlings survived by the fourth year. In contrast, seedling emergence was high and similar at forest edges and forest interiors, and was not affected by water addition. Most seedlings survived until the fourth year, with no difference between forest edge and forest interior habitats in numbers, and only minor or transient differences in size. The lack of oak regeneration in the grassland differs from previous reports on successful oak regeneration in open habitats, and may be related to a shift from light limitation to other limiting factors, such as moisture or microclimatic extremes, when moving away from the core of the deciduous forest biome towards its arid boundary. The similar number and performance of seedlings in forest edges and forest interiors may also be related to the decreasing importance of light limitation.
\end{abstract}

Keywords Pedunculate oak $\cdot$ Quercus robur $\cdot$ Forest-steppe $\cdot$ Seedling emergence $\cdot$ Temperate deciduous forest

\section{Introduction}

Temperate deciduous forests characterised by various oak, hornbeam, linden, maple, ash, and beech species cover vast areas in Europe (Schultz 2005). They harbour high species richness at the local scale show high net primary production, and possess considerable carbon sequestration capacity (Pfadenhauer and Klötzli 2014). Though the composi-

László Erdős

erdos.laszlo@ecolres.hu

1 Institute of Ecology and Botany, MTA Centre for Ecological Research, Vácrátót, Hungary

2 MTA-DE Lendület Functional and Restoration Ecology Research Group, Debrecen, Hungary

3 Institute of Biology Bucharest, Romanian Academy, Bucharest, Romania

4 Department of Biology, Savaria University Centre, Eötvös Loránd University, Szombathely, Hungary

5 Department of Ecology, University of Szeged, Szeged, Hungary

6 Department of Plant Systematics, Ecology and Theoretical Biology, Eötvös Loránd University, Budapest, Hungary tion, structure, and abiotic parameters of these forests are well studied (Pfadenhauer and Klötzli 2014), considerable debates regarding their dynamics still exist (e.g., Vera 2000; Svenning 2002; Szabó 2009; Gillian 2016). Uncertainties about the dynamics and especially the natural regeneration of temperate deciduous forests are at least partly due to the fact that most of these forests have been heavily modified by human use during the last couple of millennia, severely compromising natural processes (Ellenberg 1988; Walter and Breckle 1989; Schultz 2005; Kirby and Watkins 2015; Gillian 2016). 
Pedunculate oak (Quercus robur) is one of the most important tree species in European temperate deciduous forests, dominating lowland forests in a huge belt from Britain to the Ural Mts (Walter and Breckle 1989; Bohn et al. 2004). However, it has been recognised that the natural regeneration of this species is frequently deficient (Shaw Shaw 1968a, b; Reif and Gärtner 2007; Annighöfer et al. 2015). It is wellknown that pedunculate oak is a light-demanding species (Annighöfer et al. 2015; Leuschner and Ellenberg 2018). Therefore, its regeneration depends on open or semi-open sites with relatively high light availability, such as forest edges, hedges, shelterwoods, openings, and grasslands, and it is not successful in forest interiors (Reif and Gärtner 2007; Leuschner and Ellenberg 2018; reviewed by Bobiec et al. 2018).

Besides light availability, other key factors influencing the regeneration of pedunculate oak include water supply, competition from ground vegetation, zoochory, grazing and browsing (Vander Wall 2001; Annighöfer et al. 2015, Schäfer et al. 2019). Water supply is a critical factor during oak germination and seedling development (Dreyer et al. 1991, Bobiec et al. 2018). While water scarcity is relatively rare in Western Europe and in partially shaded habitats, its effect may be much more important in drier regions and in open habitats (Löf et al. 1998; Reif and Gärtner 2007). Competition heavily influences the survival of seedlings (Jensen and Löf 2017), but it may be reduced in sites where the herb layer is sparse or where ungulates open up the dense sward (Reif and Gärtner 2007). Grazing and browsing can affect seedling survival and performance negatively, but the nutrient reserves of the cotyledon enable oak seedlings to withstand a certain level of defoliation (Frost and Rydin 1997), while thorny shrubs and the high abundance of other, more palatable species can protect oak seedlings from grazing and browsing (Bakker et al. 2004; Jensen et al. 2012). To sum it up, an area ideal for pedunculate oak regeneration has been described as providing sufficient moisture and consisting of a mosaic of forests, thickets, shrubs, solitary trees, grasslands, and the ecotones between these habitats (Vera 2000; Bakker et al. 2004; Bobiec et al. 2018).

Biome boundaries are regions where several species reach their distributional limits, and there is a major shift in the physiognomy of the vegetation (Walter 1985; Gosz and Sharpe 1989, Neilson 1993; Peters et al. 2006, PintoLedezma et al. 2018). In these transitional zones, patches from both adjoining biomes form a mosaic pattern. Constraints operating in the transitional zones are typically different from those operating within the core areas of the biomes (Gosz and Sharpe 1989; Risser 1995). In addition, species that are dominant in the core area of the biome may become limited to specific habitats (with special microclimates) towards the biome boundary (Gosz 1992, 1993; Neilson 1993). Environmental changes, including climate change, are likely to substantially affect biome boundaries (Gosz and Sharpe 1989; Allen and Breshears 1998, Frelich and Reich 2010). Germination and establishment may be critically affected, resulting in altered dynamic processes in biome boundaries (Gosz 1992; Risser 1995; Erdős et al. 2018a).

The forest-steppe zone is at the arid boundary of the temperate deciduous forest biome: as, largely due to climatic constraints, closed-canopy forests open up and gradually give way to grasslands, a mosaic of woody and herbaceous habitats emerges (Wesche et al. 2016; Erdős et al. 2018a). Pedunculate oak is a major constituent not only in the deciduous forest biome of Europe, but also in these mosaic ecosystems (Molnár et al. 2012; Erdôs et al. 2018a). While the regeneration of pedunculate oak has been intensively studied within the core areas of the deciduous forest biome, oak regeneration patterns at the arid boundary of the biome are mostly unstudied (Bobiec et al. 2018).

In this study, our objective was to understand the effects of different habitats (forest interior, forest edge, and grassland) and watering on oak germination and early seedling performance. The experimental area lies at the arid boundary of the deciduous forest biome, where growing season precipitation strongly constrains woody vegetation, therefore, we expected that the natural regeneration of oak heavily depends on the amount of precipitation. Accordingly, our hypothesis was that oak seedling emergence and growth would be positively affected by water addition, especially in grasslands, where evapotranspiration and thus water limitation is highest. Furthermore, in line with previous studies, we also hypothesised that seedling emergence and performance would be high in grasslands (only when watered) and in forest edges, but lower and declining through time in forest interiors, because of light limitation.

\section{Materials and methods}

\section{Study area}

The Kiskunság Sand Ridge in Central Hungary lies at the arid boundary of the temperate deciduous forest biome. The area is the most arid part of the Carpathian Basin, with a mean annual temperature of $10.5{ }^{\circ} \mathrm{C}\left(17.4{ }^{\circ} \mathrm{C}\right.$ in the growing season from April to September), and a mean annual precipitation of $530 \mathrm{~mm}$ (310 $\mathrm{mm}$ in the growing season) (Dövényi 2010). The area is characterised by stabilised calcareous sand dunes, with humus-poor sandy soils (Várallyay 1993). Due to a combination of semiarid climate and coarsetextured sandy soil, forests open up and the potential vegetation is forest-steppe, with both forests and grasslands being natural and permanent elements of the landscape, and forming a mosaic (Erdős et al. 2018a). 
Pedunculate oak, a characteristic species of the temperate deciduous forests, is also present in this forest-steppe mosaic (Rédei et al. 2020), although its abundance is highly variable and is strongly affected by land use in the past centuries (Biró et al 2013, Erdős et al. 2015). The study area is located near Fülöpháza, Central Hungary; N 4652', E $19^{\circ} 25^{\prime}$ ) (Fig. 1a), where pedunculate oak is currently relatively rare, most likely due to previous land use, but the species is a typical component in several forest-steppe areas in the region.

The forest component of the vegetation mosaic at the study area is represented by the juniper-poplar forest Junipero-Populetum albae. The canopy layer is formed mainly by $12-15 \mathrm{~m}$ tall Populus alba individuals. For trees with DBH over $5 \mathrm{~cm}$, stand density is 1450 trees/ha (Erdős et al. 2018b). The shrub layer is dominated by Juniperus communis and Crataegus monogyna. The most frequent species of the herb layer are Asparagus officinalis, Carex flacca, $C$. liparicarpos, Poa angustifolia, and the seedlings of trees and shrubs.

Among the various grassland communities of the study area, the open perennial sand grassland Festucetum vaginatae is the most widespread. Its dominant species are Festuca vaginata, Stipa borysthenica, and S. capillata, while Alkanna tinctoria, Dianthus serotinus, Euphorbia seguieriana, Fumana procumbens, and Poa bulbosa are also common.

The contact zones of the forest patches and the grasslands host specific edge communities with various shrubs (e.g. Berberis vulgaris, Crataegus monogyna, Juniperus communis) and a high density of Populus alba saplings. The most frequent and abundant species of the herb layer include Calamagrostis epigeios, Festuca rupicola, Pimpinella saxifraga, and Taraxacum laevigatum.
A
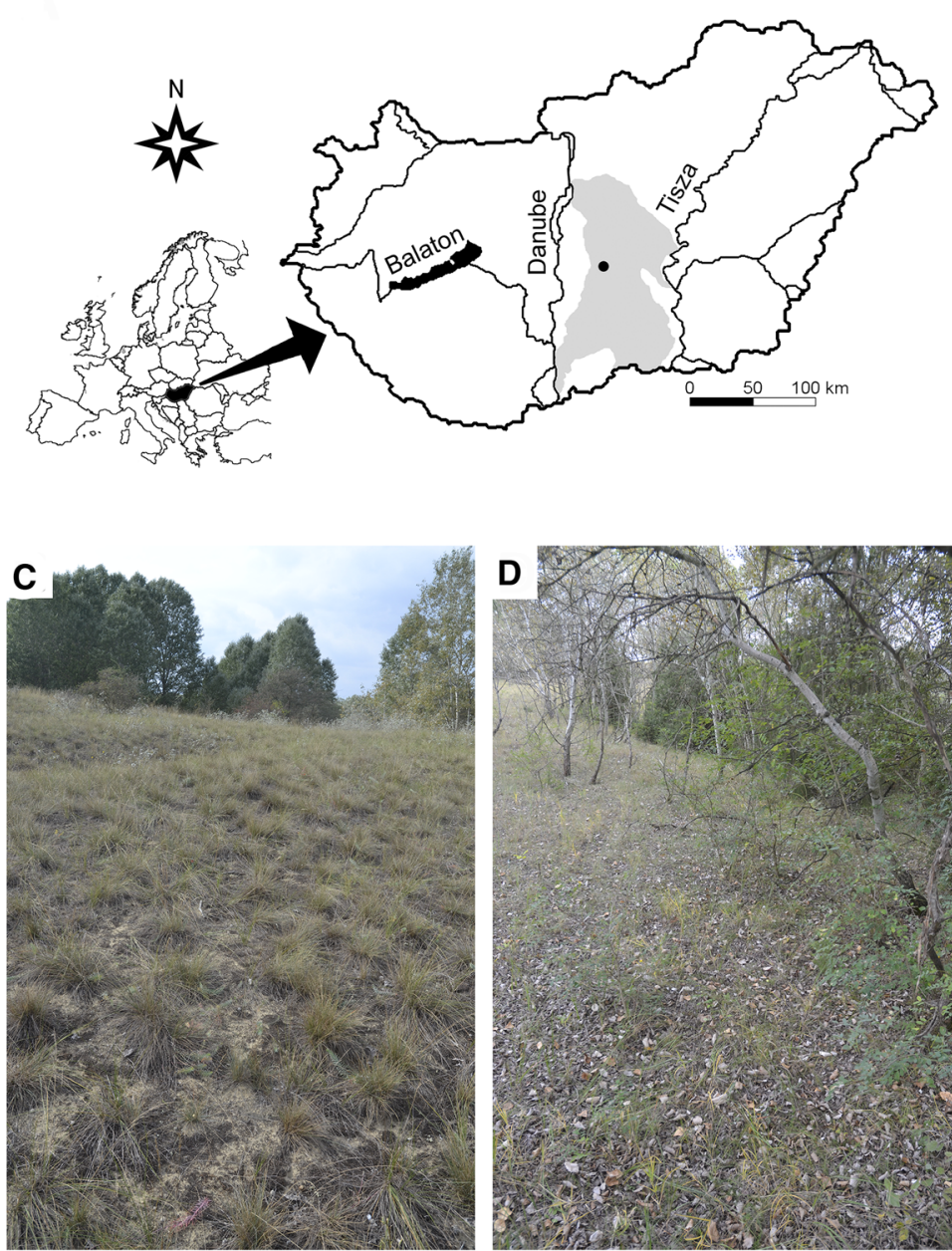

B
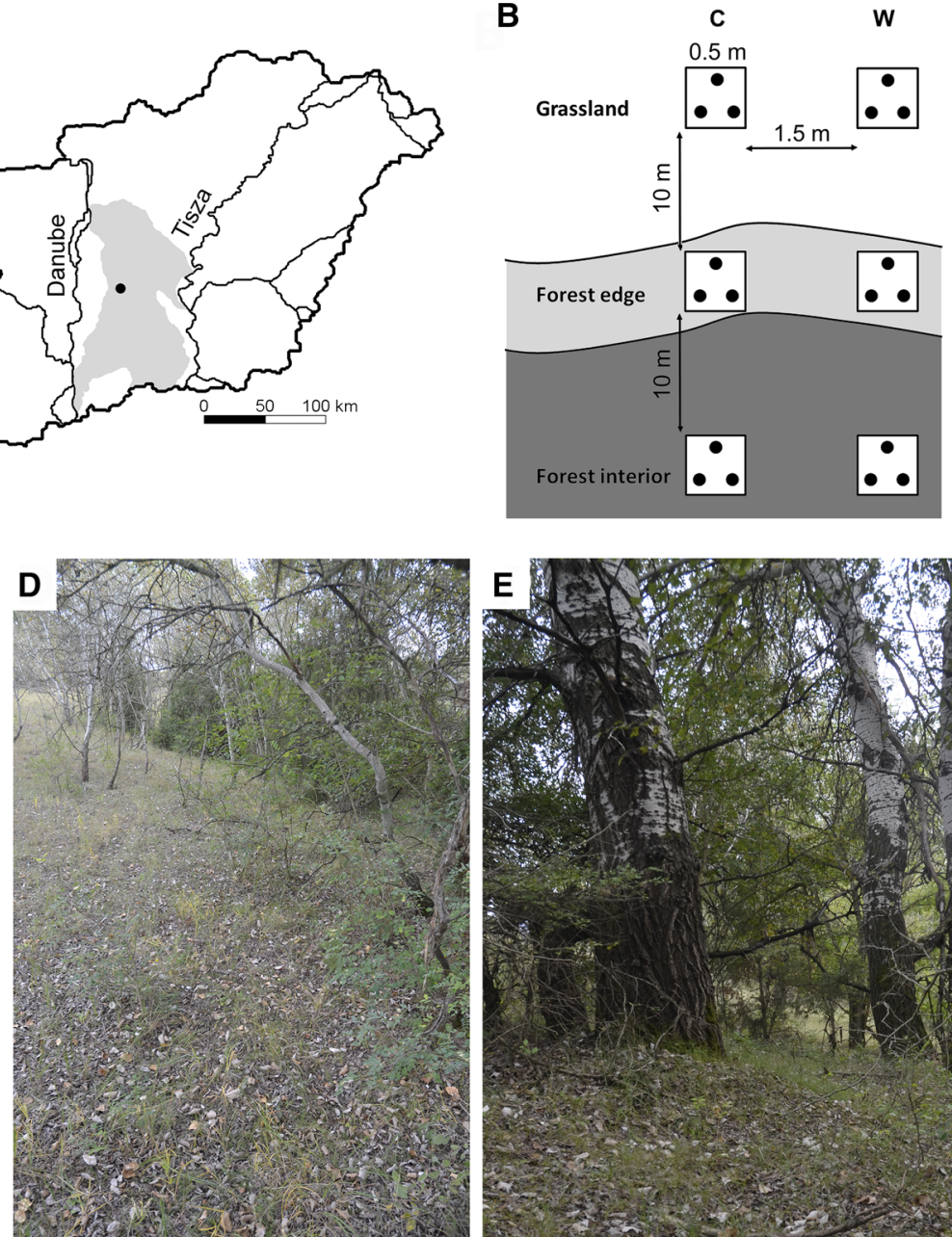

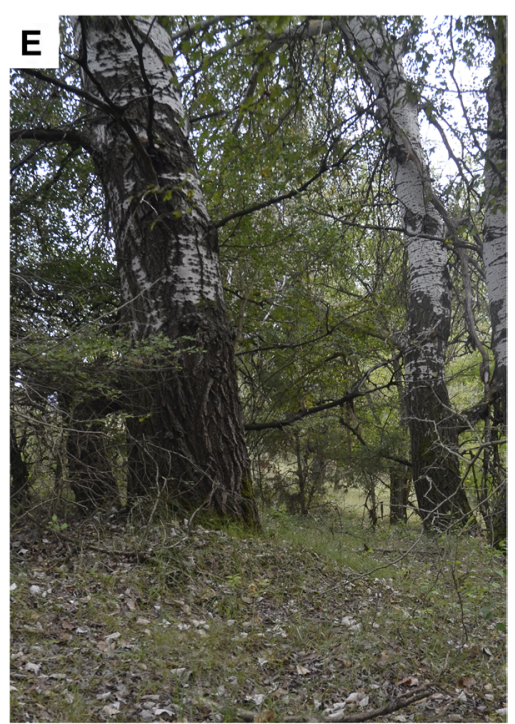

Fig. 1 The position of the study area (black dot) in the Kiskunság Sand Ridge (grey shading) (a), the experimental design with oak acorns (black dots) in the $0.5 \mathrm{~m} \times 0.5 \mathrm{~m}$ plots in the three habitats under study (C: control plots, W: watered plots) (b), the grassland habitat (c), the forest edge habitat (d), and the forest interior habitat (e) 
The study area belongs to the Kiskunság National Park; it is strictly protected, and every major human activity except research and controlled tourism has been banned since 1975 . The browsing pressure by native ungulates (mostly roe deer) is relatively low, but no particular study assessed this issue in the region. The study area is part of the KISKUN Longterm Ecological Research platform (KISKUN LTER, https:// deims.org/124f227a-787d-4378-bc29-aa94f29e1732).

The plant species names follow Király (2009), while the plant community names are used according to Borhidi et al. (2012).

\section{Experimental design}

Quercus robur acorns were collected in October 2015 from a nearby patch of seed producing oaks. To exclude acorns with reduced viability, we carried out visual inspection and a float test. The float test is reliable in identifying aborted, diseased, insect-infested or otherwise damaged acorns (Gribko and Jones 1995).

Sixteen sites were selected within a ca. $400 \mathrm{~m} \times 1100 \mathrm{~m}$ area in a natural forest-grassland mosaic. For each site, three habitats were defined: forest interior (within the forest patch, $10 \mathrm{~m}$ from the forest edge), forest edge (the zone outside of the outermost tree trunks but still under the canopy, on the northern side of forest patches), and grassland (a neighbouring treeless area, $10 \mathrm{~m}$ from the edge). At each habitat, two $0.5 \mathrm{~m} \times 0.5 \mathrm{~m}$ plots were designated in a row parallel to the forest edge. Within both plots, three acorns were planted at a depth of $2 \mathrm{~cm}$ in November 2015 (Fig. 1b-e). A total of 288 acorns was used in the experiment $(16$ sites $\times 3$ habitats $\times 2$ plots $\times 3$ acorns).

At each site and habitat, we applied two precipitation treatments in the two plots: one plot received ambient precipitation (control), while the other plot received additional watering ten times between 5 April and 6 September in their first year (2016). Watering was started in April, because temperature is low until March (ca. $6{ }^{\circ} \mathrm{C}$ mean temperature in March) and no water limitation occurs during wintertime. For watering, we used rainwater collected nearby, and the amount added corresponded to $15 \mathrm{~mm}$ precipitation each time, resulting in a total of $150 \mathrm{~mm}$ watering during the year. The additional watering was $36.5 \%$ of the natural precipitation in the growing season and $20.2 \%$ of the yearly precipitation in 2016.

Seedlings were individually censused every two or 3 weeks in the first year. The performance of the seedlings was measured near the end of the growing season of the first and the fourth years (19 September 2016 and 25 September 2019 , respectively), by registering the following parameters for each plot: (1) the number of living seedlings, (2) the number of leaves per living seedling, and (3) the height of the living seedlings.
During the growing season of 2016, we measured the volumetric soil moisture content of the upper $20 \mathrm{~cm}$ every 2 or 3 weeks from 5 April till 6 September, using FieldScout TDR300 Soil Moisture Meter (Spectrum Technologies Inc). Since soil texture is very similar across the different vegetation types in the study area including grasslands and woodlands (Kröel-Dulay et al. 2019), soil water content is a good measure of soil water availability for plants in the different habitats. We measured soil water content before watering at each site and $5 \mathrm{~h}$ after watering in three a priori chosen sites. These two measurements aimed at assessing the longer (ca. 2-week-long) and the short-term (right after watering) effects of watering on the soil moisture content. For each $0.5 \mathrm{~m} \times 0.5 \mathrm{~m}$ plot, three measurements were done and then averaged. Means for the whole growing season were calculated for each plot.

The Leaf Area Index (LAI) of the woody canopy was estimated above the herbaceous layer $(25 \mathrm{~cm})$ using a LAI 2000 Plant Canopy Analyser instrument (LI-COR, Inc., Lincoln, Nebraska). The measurements were conducted in each plot at peak canopy coverage, 30 July 2016, under clear weather conditions. The total cover of the herb layer (percentage of the $0.5 \mathrm{~m} \times 0.5 \mathrm{~m}$ plot) was estimated visually on $19 \mathrm{Sep}$ tember 2016 .

\section{Statistical analyses}

All statistical analyses were carried out using the R environment version 3.4.3. (R Core Team 2017). We compared the abiotic conditions of the treated and untreated plots in the three habitat types by using linear mixed-effects (LME) models (nlme package; Pinheiro et al. 2017). We built individual models for soil moisture content before and after watering, LAI, and total herb cover. In the models, habitat type and treatment, and their interaction were used as fixed effects, while site was used as a random effect. As the soil water was measured at only three sites after watering, we analysed the short-term effect of watering by using a linear model where habitat type, watering, and site were all used as fixed effects.

A generalised mixed-effects model (GLMM) with binomial distribution was applied to assess seedling numbers. In these models, the germination success or failure of each acorn was treated as a binary response variable, while habitat type and watering were used as fixed variables, and site as a random variable. Individual models were built for each time. As no seedling survived in the grassland till the fourth year, we did not consider the effect of this habitat type in the respective model.

The effect of habitat type and watering treatment on the leaf number and height of the oak seedlings in both 2016 and 2019 were assessed by applying LME models. In these models, we did not consider the grassland habitat type, as 
too few seedlings survived in the grassland plots (only 4 individuals by the end of 2016 and none till 2019). Leaf numbers and height data were square-root transformed to meet the homogeneity and normality assumptions of the tests.

We made visual assessments of the residual diagnostic plots to check the assumptions of the tests. For post hoc pairwise comparisons, we performed Tukey tests using the multcomp package (Hothorn et al. 2016).

\section{Results}

\section{Inherent differences among the studied habitats}

The cover of the herb layer was similar in the grassland and the forest edge habitats, while it was much lower in the forest interior habitat (Table 1, Fig. 2a). Note that the cover of the herb layer was relatively low (below 50\%) even in the grassland and the forest edge habitats. The LAI of the overstorey vegetation showed marked differences among the habitats, with the lowest value in grasslands, intermediate values at the forest edges, and the highest values in the forest interiors (Fig. 2b). Average growing season soil moisture content was the lowest in grasslands,

Table 1 Linear mixed-effects and linear model results of the effects of habitat type, watering on the total cover of the herb layer, soil moisture content before and $5 \mathrm{~h}$ after watering, and leaf area index (LAI)

\begin{tabular}{lcrl}
\hline Variables and effects & $d f$ & $F$ & $P$ \\
\hline Total herb cover & & 16.9 & \\
Habitat type & 1 & 0.9 & 0.350 \\
Watering & 2 & 0.1 & 0.891 \\
Habitat type $\times$ watering & & & \\
LAI & 2 & 318.7 & $\mathbf{0 . 0 0 0}$ \\
Habitat type & 1 & 1.0 & 0.344 \\
Watering & 2 & 0.2 & 0.844 \\
Habitat type $\times$ watering & 2 & & \\
Soil moisture content right after watering & 66.2 & $\mathbf{0 . 0 0 0}$ \\
Habitat type & 1 & 315.1 & $\mathbf{0 . 0 0 0}$ \\
Watering & 2 & 0.3 & 0.774 \\
Site & 2 & 14.4 & $\mathbf{0 . 0 0 1}$ \\
Habitat type $\times$ watering & 2 & & \\
Soil moisture content ca. 2 weeks after watering & & \\
Habitat type & 1 & 12.1 & $\mathbf{0 . 0 0 0}$ \\
Watering & 2 & 2.6 & 0.080 \\
Habitat type $\times$ watering & & & \\
\hline
\end{tabular}

$P$ values are rounded to three digits

$(P<0.05)$ values are shown in bold while it was higher and similar at the forest edge and the forest interior habitats (Fig. 2c, d; control plots).

\section{Effect of watering treatment on soil moisture content}

Watering substantially increased soil moisture content in all the three habitats right after watering (Fig. 2c), and some of this effect remained even ca. 2 weeks after watering (before the next watering), although post hoc tests showed that this was only significant in the forest interior habitats (Fig. 2d).

\section{Seedling emergence and survival}

Seedling emergence rate was very low in grassland habitats (on average 0.3 acorns germinated out of 3 ), but was high (on average 2.5 out of 3 ) and similar in forest edges and forest interiors (Table 2, Fig. 3a). Water addition did not affect the emergence rate (Table 2, Fig. 3a). Even the few seedlings that emerged in grasslands died by the fourth year, September 2019 (Fig. 3c). Seedling number remained high (on average 2) in forest edge and forest interior habitats until September 2019, and was affected neither by habitat (forest edge vs. forest interior) nor by water addition (Table 2 , Fig. $3 b-c)$.

\section{Seedling performance}

In September 2016, there was no difference in the leaf number of the seedlings between the forest edge and the forest interior habitats (Table 2, Fig. 4a), while in September 2019, seedlings in forest edges had more leaves than seedlings in forest interiors (Table 2, Fig. 4b). Seedlings were taller in the forest interior habitat in 2016 (Fig. 4c), but there was no difference in plant height between the habitats in 2019 (Fig. 4d). Watering had no effect on leaf number and plant height at either time (Table 2, Fig. 4). In general, oak seedlings grew very little from 2016 to 2019, and were still very short and had few leaves at the age of 4 years (Fig. 4).

\section{Discussion}

In contrast to our first hypothesis, watering throughout the growing season did not improve oak seedling emergence and subsequent seedling performance, and this was consistent across all habitat types. Oak seedling emergence and seedling survival were extremely low in the grassland habitat, which is in contrast to previous reports from the core areas of the deciduous forest biome, where pedunculate oak most often regenerates in open or semi-open habitats (Bakker et al. 2004; Bobiec et al. 2018). We did not find a negative effect of the forest interiors compared to forest edges 
A

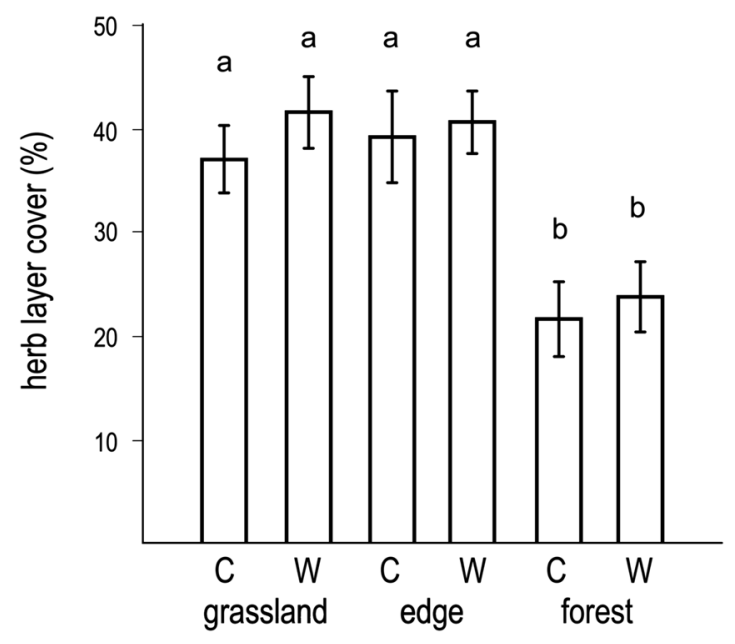

C

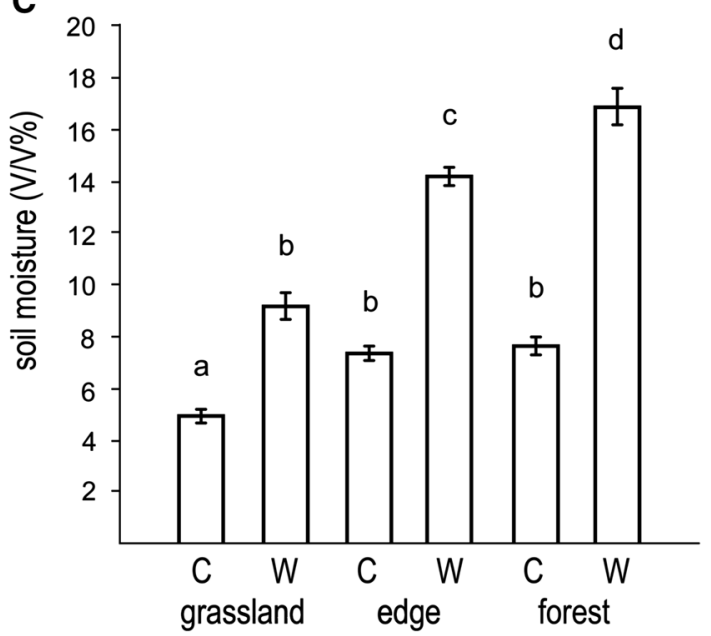

B

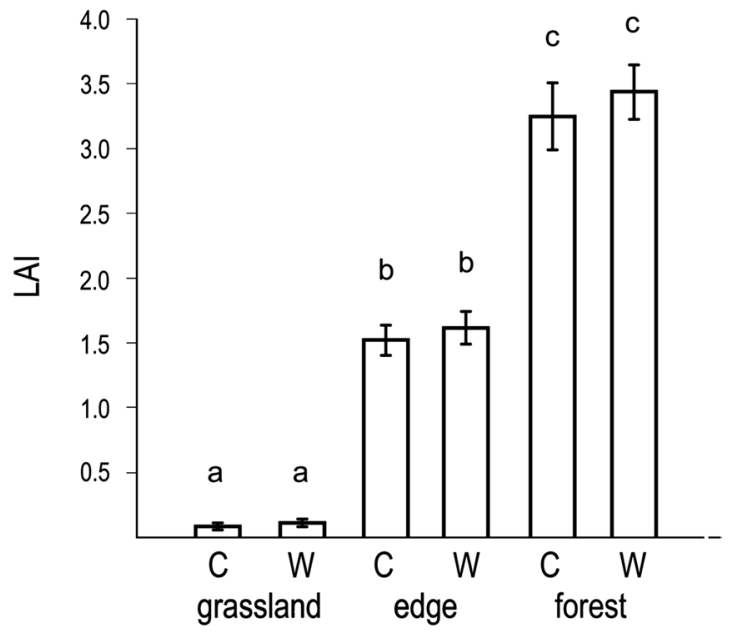

D

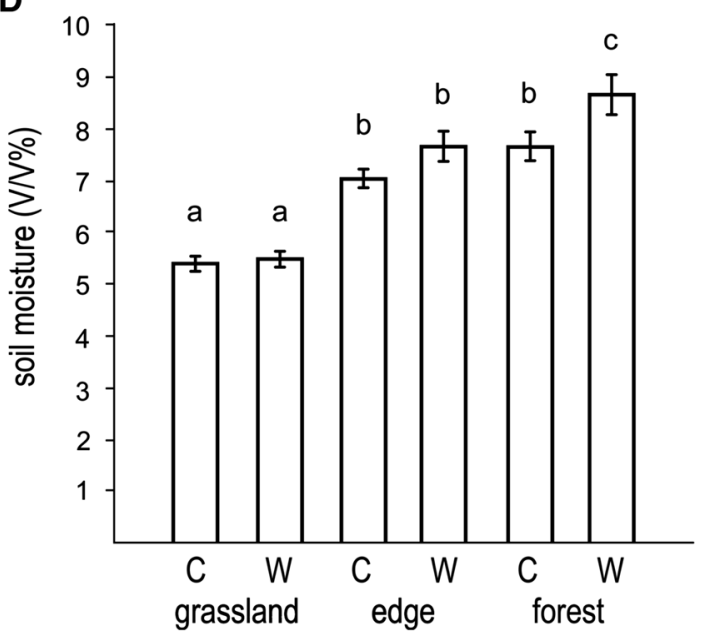

Fig. 2 The cover of the herb layer (a), leaf area index (b), soil moisture content $5 \mathrm{~h}$ after watering (c), and soil moisture content 2 weeks after watering (d) in the three habitats (grassland, forest edge, and forest interior). C: control plots, W: watered plots

on seedling numbers and performance throughout the four years of the study, while previous studies reported that the shade tolerance of oak seedlings is very low (Lorimer et al. 1994; Welander and Ottosson 1998; Leuschner and Ellenberg 2018). These results suggest that patterns of early oak regeneration at this site at the arid boundary of the temperate deciduous forest biome substantially differ from those previously reported from the core area of the biome. This is most likely related to a shift in oak regeneration from light limitation in the core zone to other limiting factors at the biome boundary.

\section{Effect of watering}

Even though we managed to substantially increase soil moisture content during the experiment, excess water had no effect on oak regeneration, which is in striking contrast to our expectation. The pot experiment of van Hees (1997) showed that moist conditions positively affect the height, biomass, and leaf area of $Q$. robur seedlings. The study of Urli et al. (2015) revealed that $Q$. robur seedlings and saplings react sensitively to drought stress in Southwest France and are not able to survive under very dry circumstances. In a Mediterranean mountain environment, Mendoza et al. (2009) found that watering increased the survival of $Q$. ilex and $Q$. pyrenaica seedlings in open and shrubby habitats, while it was not affected under tree canopies, where survival was high even in the absence of watering. In a similar study conducted in Mediterranean ecosystems, Matías et al. (2012a, b) showed that additional watering during the summer is able to increase the survival of $Q$. ilex seedlings in open, shrubby, and forest habitats. 
Table 2 Results of generalised linear mixed-effects model and linear mixed-effects models of habitat type and watering treatment on germinated seedling number, leaf number, and plant height

\begin{tabular}{|c|c|c|c|}
\hline Variables and effects & $d f$ & Chisq & $P$ \\
\hline \multicolumn{4}{|l|}{ Germinated seedlings } \\
\hline Habitat type & 2 & 34.09 & $\mathbf{0 . 0 0 0}$ \\
\hline Watering & 1 & 0.04 & 0.841 \\
\hline Habitat type $\times$ watering & 2 & 0.94 & 0.625 \\
\hline \multicolumn{4}{|c|}{ Seedling number in September 2016} \\
\hline Habitat type & 2 & 28.86 & 0.000 \\
\hline Watering & 1 & 0.01 & 0.937 \\
\hline Habitat type $\times$ watering & 2 & 1.18 & 0.553 \\
\hline \multicolumn{4}{|c|}{ Seedling number in September 2019} \\
\hline Habitat type & 1 & 0.04 & 0.832 \\
\hline Watering & 1 & 0.04 & 0.832 \\
\hline Habitat type $\times$ watering & 1 & 0.39 & 0.532 \\
\hline \multicolumn{4}{|c|}{ Leaf number in September 2016} \\
\hline Habitat type & 1 & 2.44 & 0.118 \\
\hline Watering & 1 & 0.03 & 0.872 \\
\hline Habitat type $\times$ watering & 1 & 0.45 & 0.504 \\
\hline \multicolumn{4}{|c|}{ Leaf number in September 2019} \\
\hline Habitat type & 1 & 6.14 & 0.013 \\
\hline Watering & 1 & 0.78 & 0.378 \\
\hline Habitat type $\times$ watering & 1 & 0.24 & 0.622 \\
\hline \multicolumn{4}{|c|}{ Plant height in September 2016} \\
\hline Habitat type & 1 & 5.60 & 0.018 \\
\hline Watering & 1 & 3.00 & 0.083 \\
\hline Habitat type $\times$ watering & 1 & 0.01 & 0.937 \\
\hline \multicolumn{4}{|c|}{ Plant height in September 2019} \\
\hline Habitat type & 1 & 0.73 & 0.393 \\
\hline Watering & 1 & 1.18 & 0.277 \\
\hline Habitat type $\times$ watering & 1 & 0.15 & 0.703 \\
\hline
\end{tabular}

$P$ values are rounded to three digits

$(P<0.05)$ values are shown in bold

The lack of response to watering in our experiment may be related to the fact that 2016 was an unusually wet year. Yearly total precipitation in 2016 was $742 \mathrm{~mm}$, compared to the long-term mean of $530 \mathrm{~mm}$; and growing season precipitation was $410 \mathrm{~mm}$, compared to the long-term mean of $310 \mathrm{~mm}$. The fact that even a year of above-average precipitation combined with excess water resulted in very low emergence and no survival in grassland patches suggests that grasslands are truly incapable of supporting oak regeneration in this ecosystem.

In our experiment, watering lasted throughout the growing season, from early April to September. Although we did not assess potential effect of water limitation outside the growing season, the cool temperature combined with usually substantial water in this period (an average 30-50 mm per month, Kovács-Láng et al 2000) makes water limitation unlikely.

\section{Effect of habitat type}

In contrast to our hypothesis that the forest edge would represent the best habitat for seedlings while the grassland (due to drought) and the forest interior (due to shade) habitats would be less suitable, we found that seedling emergence and performance were extremely poor in grasslands while they were high in forest edges and forest interiors. Thus, forest edges and forest interiors proved to be similarly suitable for early oak regeneration, despite the strong differences regarding abiotic parameters in these two habitats. It is possible that increased soil moisture in forest interiors and forest edges compensate seedlings for the shady conditions; a similar compensatory effect has been described by Mellert et al. (2018).

Oak regeneration was absent in the grassland habitat: seedling emergence was extremely low and the few seedlings that did emerge died by September 2019. This finding differs from earlier studies conducted in the temperate deciduous forest biome. For example, Bakker et al. (2004) found that the survival and performance of pedunculate oak seedlings was better in grasslands than in forest interiors in riverine floodplains of western Europe (Germany, the Netherlands, and Great Britain). Similarly, Q. robur is able to colonise abandoned ploughlands and pastures as shown in France (Onaindia et al. 2001) and Poland (Bobiec et al. 2011b). The study of Olrik et al. (2012) showed successful colonisation by pedunculate oak in a heathland in Denmark, while oak can occupy abandoned pastures in Poland and Ukraine (Ziobro et al. 2016). In Belgium, several non-woody vegetation types such as grasslands, ruderal fields, and bramble thickets proved to be appropriate for $Q$. robur emergence (Van Uytvanck et al. 2008). Thus, it seems that $Q$. robur can easily regenerate in open (i.e. non-woody) habitats in the core areas of the temperate deciduous forest biome (Bobiec et al. 2018).

However, studies from Mediterranean habitats with oak species other than pedunculate oak indicated that oak regeneration may be limited in open habitats. For example, Mendoza et al. (2009) reported from southern Spain that the seedling survival of two Mediterranean oak species, $Q$. ilex and $Q$. pyrenaica, was the lowest in open habitats, while it was much higher under shrubs and in woodlands. Matías et al. (2012b) found that the emergence of $Q$. ilex was very good in open habitats, but the survival of the seedlings was poor in the same habitat, presumably due to drought stress. Similarly, in southern France, Rousset and Lepart (2000) showed that the germination and survival of $Q$. humilis was 
Fig. 3 The number of germinated oak individuals (a), individuals that survived until September 2016 (b), and until September 2019 (c) in the three habitats (grassland, forest edge, and forest interior). C: control plots, W: watered plots

better under shrubs than in the neighbouring grassland, as shrubs protected the seedlings from drought. In Mediterranean California, the seedling transplantation study of LópezSánchez et al. (2019) revealed that almost all seedlings of $Q$. lobata and $Q$. agrifolia died in the open grassland, while they had significantly higher survival rates under trees and shrubs, where they were more protected from drought stress.

Desiccation is a critical factor during oak germination and seedling growth (Bobiec et al. 2018). Low soil moisture seems to be the most likely cause of poor seedling emergence and performance in the grassland habitat in our study, besides other factors, discussed below. Water limitation is the most prominent ecological constraint in the centre of the Carpathian Basin, with a semi-arid period during the summer months according to the long-term climate records (Borhidi 1993; Kun 2001). In addition, the sandy soils of the study site have very poor water retention capacity (Várallyay 1993), further decreasing water availability. While water limitation is relatively rare in the western and northern parts of Europe (within the core area of the temperate deciduous forest biome) (Reif and Gärtner 2007), it seems to be of primary importance at the arid boundary of the biome. However, the overriding role of water limitations in grasslands could only be proved by a more intense watering treatment (e.g. watering more frequently, or with higher amount, or starting already in autumn).

Competition with ground vegetation is usually considered one of the most important factors limiting oak regeneration (e.g. Vander Wall 2001; Reif and Gärtner 2007; Annighöfer et al. 2015). However, we think it cannot explain the strikingly poor oak regeneration in grasslands. First, the total cover of the herb layer was very low ( $40 \%$ or even less) in the grasslands of the study. Thus, there was ample space for oak seedlings to establish. Second, the cover of the herb layer was similar in the grasslands and the forest edges, yet forest edges had much higher seedling emergence and performance rates.

The poor oak germination and performance of the grassland habitat cannot be explained by browsing or predation either (Bobiec et al. 2018). Browsing pressure is generally low in the area, and we did not see signs of heavy browsing pressure on the seedlings during our regular surveys. Seed predation is also unlikely to differ substantially among the three habitats, due to the small distances (few metres) between the forest interior, forest edge, and grassland plots, and we did not see signs of predation (e.g. soil disturbance).

Further factors potentially limiting oak regeneration include high solar radiation and the lack of a humus layer
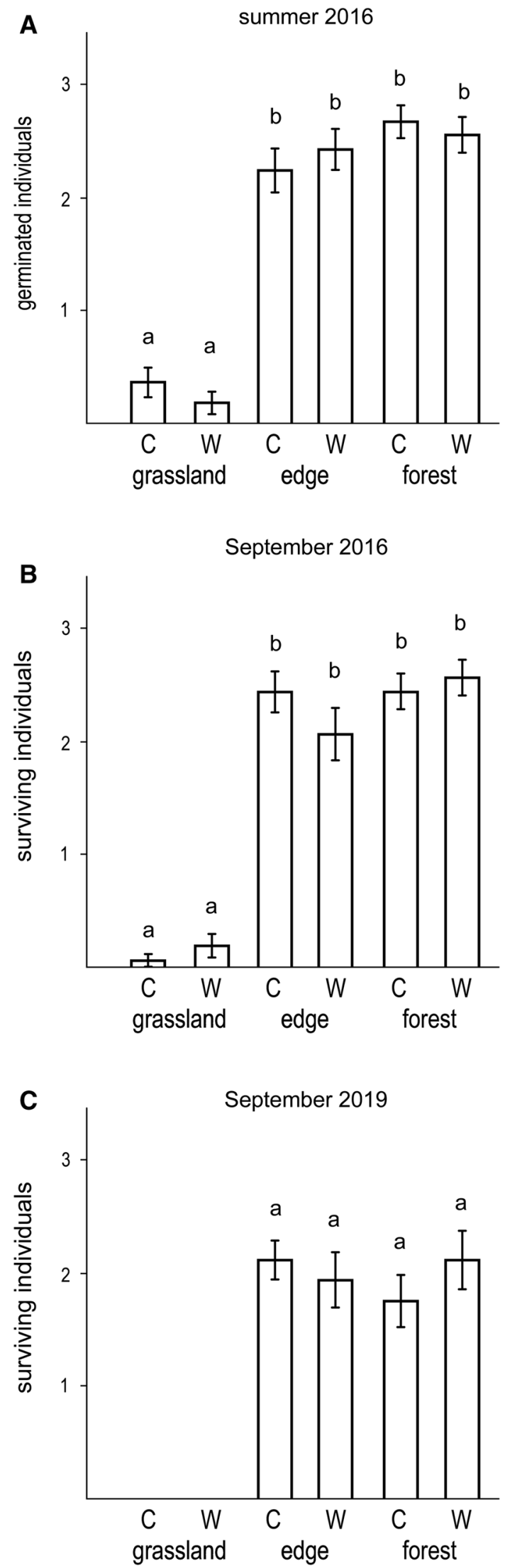
A

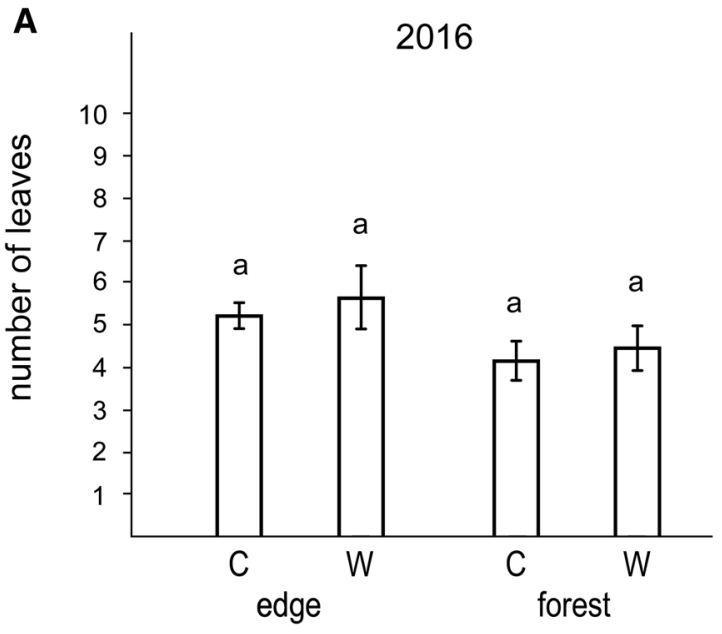

C

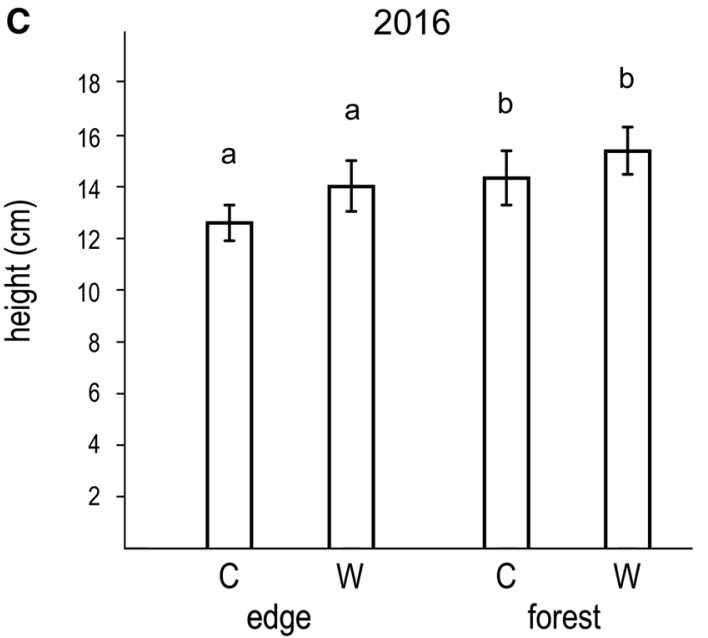

B

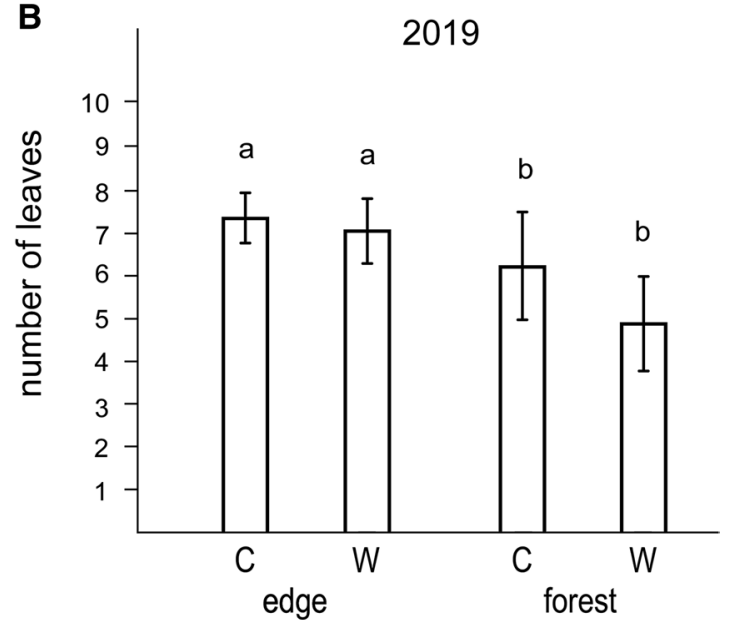

D

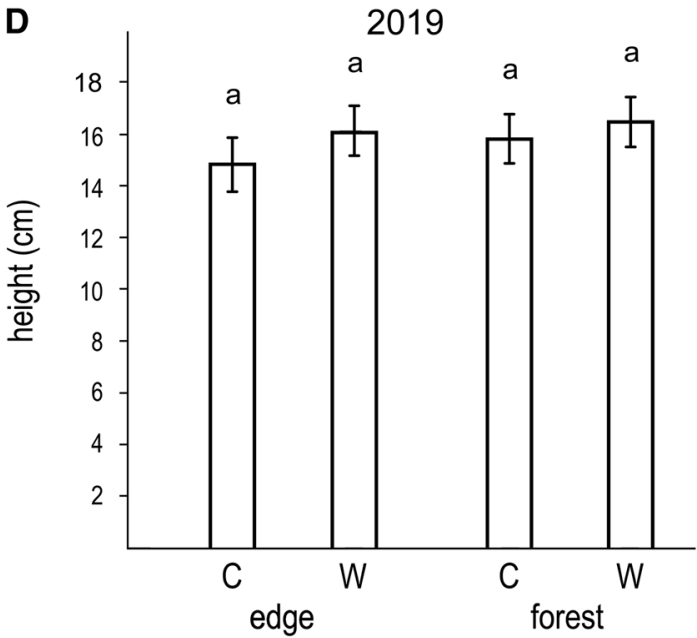

Fig. 4 The number of leaves in September 2016 (a), the number of leaves in September 2019 (b), the height of the seedlings in September 2016 (c), and the height of the seedlings in September 2019 (d) in the forest edge and forest interior habitats. C: control plots, W: watered plots

(Nilsson et al. 1996), both of which might have affected seedling emergence and survival in our study. The influence of high solar radiation may be amplified by the very sparse herb layer, and may contribute to the drying of the soil. Regarding the humus layer, the sandy soil of the grassland habitat in the study site is extremely poor in humus: the humus content of the upper $10 \mathrm{~cm}$ soil layer can be as low as $0.6 \%$, while it is considerably higher in the forest patches (Bodrogközy 1982; Várallyay 1993; Kröel-Dulay et al. 2019; Tölgyesi et al. 2020).

Microclimatic extremes may also contribute to the poor oak emergence and survival in the grassland habitat. High air temperatures measured near the soil surface in the grassland habitat during summer days (compared to the much cooler forest edges and forest interiors) (e.g. Erdős et al. 2014; Tölgyesi et al. 2020) may damage the tissues and physiological processes of pedunculate oak (Cuza 2018), thus preventing oak regeneration in this habitat.

Our study revealed similarly high early oak regeneration in forest edges and forest interiors. Good oak regeneration within the forest edge habitat fits our hypothesis and is in line with earlier observations regarding habitats optimal for oak regeneration (e.g. Vera 2000; Reif and Gärtner 2007; Bobiec et al. 2018). For example, Herlin and Fry (2000) showed that $Q$. robur is able to establish in forest edges and hedgerows in southern Sweden. Similarly, Bakker et al. (2004) found that edges are optimal habitats for $Q$. robur regeneration throughout northwestern Europe.

We found only small and transient differences between forest edge and forest interior habitats. Seedlings in the forest interiors had fewer leaves than seedlings in forest edges, although the difference was significant only in 2019. This result is in line with earlier studies reporting 
reduced leaf number in seedlings under shady conditions (e.g. Ziegenhagen and Kausch 1995; Welander and Ottosson 1998). Seedlings were higher in forest interiors than in forest edges in 2016, while no significant difference was found in 2019. Seedlings are usually higher in shady than in sunny habitats (e.g. Ziegenhagen and Kausch 1995; Nilsson et al. 1996; van Hees 1997; Ammer 2003).

The overall similarity of forest interiors and forest edges is surprising given the reported high light requirements of pedunculate oak seedlings. According to Leuschner and Ellenberg (2018), the shade tolerance of $Q$. robur seedlings is very low. Indeed, the regeneration of pedunculate oak depends primarily on non-forest habitats (Bakker et al. 2004; Bobiec et al. 2018). However, it has also been shown that seedlings do tolerate shady conditions during the first few years; that is, their light demand starts to increase only after those initial years (e.g. Welander and Ottosson 1998; Vander Wall 2001; Annighöfer et al. 2015). Von Lüpke and Hauskeller-Bullerjahn (2004) and Bobiec et al. (2011a) found that young oak individuals are increasingly dependent on clearings as they grow up. Ziegenhagen and Kausch (1995) argued that the starch reserves of the young seedlings enable them to survive in shade for a couple of years. Although a negative effect of shading in the forest interiors may easily be seen in the future, the lack of such difference in the first four years is interesting given the above reports on low shade tolerance of pedunculate oak. One possible explanation may be that forest interiors at our site are not as closed as forests in the biome interior (see picture in Fig. 1e). Indeed, the LAI of 3-3.5 measured at our forest interiors is lower than that reported for several temperate oak forests in Europe (e.g. Bréda and Granier 1996; Le Dantec et al. 2000; Soudani et al. 2006; Thimonier et al. 2010). Another explanation for the similar performance of oak seedlings at forest edges and forest interiors is that a factor other than light limits growth. A major candidate in these ecosystems can be soil moisture (Várallyay 1993), which may also explain the extremely small size of the 4-year old oak seedlings $(14-16 \mathrm{~cm})$.

\section{Differences in oak regeneration between the core area and the arid boundary of the biome}

Towards the arid boundary of the temperate deciduous forest biome, the competitive vigour of the woody lifeforms decreases (Walter and Breckle 1989; Erdôs et al. 2018a). As a consequence, forests gradually open up, enabling the emergence of the forest-steppe zone with alternating forest and grassland patches. The poor performance of our seedlings, especially regarding their height, also indicates that conditions are suboptimal for oak regeneration at our site. Seedling height has been reported to reach 13-20 cm after one (Giertych and Suszka 2010; Devetaković et al. 2019), and 30-60 cm after only two growing seasons (Ammer 2003; Cabral and O'Reilly 2008; Andersen 2010).

\section{Conclusions}

Our study suggests that oak regeneration pattern in this transitional zone differs markedly from what has been described in the core areas of the temperate deciduous forest biome. When one moves from the core areas of the deciduous forest biome towards the arid boundary of the biome, there seems to be a shift from light limitation to other limiting factors, which prevent oak regeneration in grassland patches and restrict it to forest edges, and, potentially, to forest interiors.

In conclusion, our results emphasise that oak regeneration and thus forest dynamics may be limited by different factors at a biome boundary compared to the biome core. Indeed, the lack of tree regeneration in grassland patches may contribute to the opening up of the closed forest biome, and the emergence of the forest-steppe zone.

Acknowledgements The authors are thankful for the support of the 'Momentum' Program of the Hungarian Academy of Sciences.

Funding Open Access funding provided by ELKH Centre for Ecological Research. This work was supported by the Hungarian Scientific Research Fund (Grant Number OTKA PD 116114 for László Erdős), the National Research, Development and Innovation Office (Grant Numbers NKFIH K 119225 and NKFIH KH 129483 for Péter Török, NKFIH K 124796 for Zoltán Bátori, NKFIH PD 132131 for Csaba Tölgyesi, NKFIH K 129068 for György Kröel-Dulay). Kinga Öllerer received further support from the Romanian Academy (Grant Number RO1567 IBB03/2019).

\section{Compliance with ethical standards}

Conflicts of interest The authors declare that they have no conflict of interest.

Open Access This article is licensed under a Creative Commons Attribution 4.0 International License, which permits use, sharing, adaptation, distribution and reproduction in any medium or format, as long as you give appropriate credit to the original author(s) and the source, provide a link to the Creative Commons licence, and indicate if changes were made. The images or other third party material in this article are included in the article's Creative Commons licence, unless indicated otherwise in a credit line to the material. If material is not included in 
the article's Creative Commons licence and your intended use is not permitted by statutory regulation or exceeds the permitted use, you will need to obtain permission directly from the copyright holder. To view a copy of this licence, visit http://creativecommons.org/licenses/by/4.0/.

\section{References}

Allen CD, Breshears DD (1998) Drought-induced shift of a forestwoodland ecotone: rapid landscape response to climate variation. Proc Natl Acad Sci USA 95:14839-14842

Ammer C (2003) Growth and biomass partitioning of Fagus sylvatica L. and Quercus robur L. seedlings in response to shading and small changesin the R/FR-ratio of radiation. Ann For Sci 60:163171. https://doi.org/10.1051/forest:2003009

Andersen L (2010) Spacing in the nursery seedbed and subsequent field performance of Quercus robur L. and Fagus sylvatica L. Eur J Hortic Sci 75:221-225

Annighöfer P, Beckschäfer P, Vor T, Ammer C (2015) Regeneration patterns of European oak species (Quercus petraea (Matt.) Liebl., Quercus robur L.) in dependence of environment and neighborhood. PLoS ONE 10:e0134935. https://doi.org/10.1371/journ al.pone. 0134935

Bakker ES, Olff H, Vandenberghe C, De Maeyer K, Smit R, Gleichman JM, Vera FWM (2004) Ecological anachronisms in the recruitment of temperate light-demanding tree species in wooded pastures. J Appl Ecol 41:571-582. https://doi.org/10.11 11/j.0021-8901.2004.00908.x

Biró M, Szitár K, Horváth F, Bagi I, Zs Molnár (2013) Detection of long-term landscape changes and trajectories in a Pannonian sand region: comparing land-cover and habitat-based approaches at two spatial scales. Commun Ecol 14:219-230. https://doi.org/10.1556/ comec.14.2013.2.12

Bobiec A, Jaszcz E, Wojtunik K (2011a) Oak (Quercus robur L.) regeneration as a response to natural dynamics of stands in European hemiboreal zone. Eur J For Res 130:785-797. https://doi. org/10.1007/s10342-010-0471-3

Bobiec A, Kuiper DPJ, Niklasson M, Romankiewicz A, Solecka K (2011b) Oak (Quercus robur L.) regeneration in early successional woodlands grazed by wild ungulates in the absence of livestock. For Ecol Manag 262:780-790. https://doi.org/10.1016/j. foreco.2011.05.012

Bobiec A, Reif A, Öllerer K (2018) Seeing the oakscape beyond the forest: a landscape approach to the oak regeneration in Europe. Landsc Ecol 33:513-528. https://doi.org/10.1007/s1098 0-018-0619-y

Bodrogközy G (1982) Hydroecology of the vegetation of sandy foreststeppe character in the Emlékerdő at Ásotthalom. Acta Biol Szeged 28:13-39

Bohn U, Gollub G, Hettwer C, Neuhäuslová Z, Raus T, Schlüter H, Weber H (2004) Map of the natural vegetation of Europe. Bundesamt für Naturschutz, Bonn

Borhidi A (1993) Characteristics of the climate of the Danube-Tisza Mid-Region. In: Szujkó-Lacza J, Kováts D (eds) The flora of the Kiskunság National Park I. Hungarian Natural History Museum, Budapest, pp 9-20

Borhidi A, Kevey B, Lendvai G (2012) Plant communities of Hungary. Academic Press, Budapest

Bréda N, Granier A (1996) Intra- and interannual variations of transpiration, leaf area index and radial growth of a sessile oak stand (Quercus petraea). Ann For Sci 53:521-536. https://doi. org/10.1051/forest:19960232
Cabral R, O'Reilly C (2008) Physiological and field growth responses of oak seedlings to warm storage. New For 36:159-170. https:// doi.org/10.1007/s11056-008-9090-y

Cuza P (2018) The use of experimental botanical methods to determine the resistance of pedunculate oak and downy oak to heat stress. Rev Bot 2:5-13

Devetaković J, Nonić M, Prokić B, Popović V, Šijačić-Nikolić M (2019) Acorn size influence on the quality of pedunculate oak (Quercus robur L.) one-year old seedlings. Reforesta 8:17-24. https://doi.org/10.21750/REFOR.8.02.72

Dövényi Z (ed) (2010) Magyarország kistájainak katasztere. MTA FKI, Budapest

Dreyer E, Colin-Belgrand M, Biron P (1991) Photosynthesis and shoot water status of seedlings from different oak species submitted to waterlogging. Ann For Sci 48:205-214. https://doi.org/10.1051/ forest: 19910207

Ellenberg H (1988) Vegetation ecology of Central Europe, 4th edn. Cambridge University Press, Cambridge

Erdős L, Tölgyesi C, Horzse M, Tolnay D, Hurton Á, Schulcz N, Körmöczi L, Lengyel A, Bátori Z (2014) Habitat complexity of the Pannonian forest-steppe zone and its nature conservation implications. Ecol Complex 17:107-118. https://doi. org/10.1016/j.ecocom.2013.11.004

Erdős L, Tölgyesi C, Cseh V, Tolnay D, Cserhalmi D, Körmöczi L, Gellény K, Bátori Z (2015) Vegetation history, recent dynamics and future prospects of a Hungarian sandy forest-steppe reserve: forest-grassland relations, tree species composition and size-class distribution. Commun Ecol 16:95-105. https://doi. org/10.1556/168.2015.16.1.11

Erdős L, Ambarlı D, Anenkhonov OA, Bátori Z, Cserhalmi D, Kiss M, Kröel-Dulay G, Liu H, Magnes M, Molnár Z, Naqinezhad A, Semenishchenkov YA, Tölgyesi C, Török P (2018a) The edge of two worlds: a new review and synthesis on Eurasian foreststeppes. Appl Veg Sci 21:345-362. https://doi.org/10.1111/ avsc. 12382

Erdős L, Gy Kröel-Dulay, Bátori Z, Kovács B, Cs Németh, Kiss PJ, Tölgyesi C (2018b) Habitat heterogeneity as a key to high conservation value in forest-grassland mosaics. Biol Conserv 226:72-80. https://doi.org/10.1016/j.biocon.2018.07.029

Frelich LE, Reich PB (2010) Will environmental changes reinforce the impact of global warming on the prairie-forest border of central North America? Front Ecol Environ 8:371-378. https://doi. org/10.1890/080191

Frost I, Rydin H (1997) Effects of competition, grazing and cotyledon nutrient supply on growth of Quercus robur seedlings. Oikos 79:53-58. https://doi.org/10.2307/3546089

Giertych MJ, Suszka J (2010) Influence of cutting off distal ends of Quercus robur acorns on seedling growth and their infection by the fungus Erysiphe alphitoides in different light conditions. Dendrobiology 64:73-77

Gillian FS (2016) Forest ecosystems of temperate climaticregions: from ancient use to climate change. New Phytol 212:871-887. https://doi.org/10.1111/nph.14255

Gosz JR (1992) Ecological functions in a biome transition zone: Translating local responses to broad-scale dynamics. In: Hansen AJ, di Castri F (eds) Landscape boundaries. Springer, New York, pp 55-75. https://doi.org/10.1007/978-1-4612-2804-2_3

Gosz JR (1993) Ecotone hierarchies. Ecol Appl 3:369-376. https://doi. org/10.2307/1941905

Gosz JR, Sharpe JH (1989) Broad-scale concepts for interactions of climate, topography, and biota at biome transitions. Landsc Ecol 3:229-243. https://doi.org/10.1007/BF00131541

Gribko LS, Jones WE (1995) Test of the float method of assessing northern red oak acorn condition. Tree Plant Notes 46:143-147

Herlin ILS, Fry GLA (2000) Dispersal of woody plants in forest edges and hedgerows in a Southern Swedish agricultural area: the role 
of site and landscape structure. Landsc Ecol 15:229-242. https:// doi.org/10.1023/A:1008170220639

Hothorn T, Bretz F, Westfall P, Heiberger RM, Schuetzenmeister A, Scheibe S, Hothorn MT (2016) Package 'multcomp'. Simultaneous inference in general parametric models. Project for Statistical Computing, Vienna

Jensen AM, Löf M (2017) Effects of interspecific competition from surrounding vegetation on mortality, growth and stem development in young oaks (Quercus robur). For Ecol Manag 392:176183. https://doi.org/10.1016/j.foreco.2017.03.009

Jensen AM, Götmark F, Löf M (2012) Shrubs protect oak seedlings against ungulate browsing in temperate broadleaved forests of conservation interest: a field experiment. For Ecol Manag 266:187-193. https://doi.org/10.1016/j.foreco.2011.11.022

Király G (ed) (2009) Uj magyar füvészkönyv. Aggteleki Nemzeti Park Igazgatóság, Jósvafő

Kirby KJ, Watkins C (eds) (2015) Europe's changing woods and forests from wildwoods to managed landscapes. CABI, Wallingford

Kovács-Láng E, Kröel-Dulay G, Kertész M, Fekete G, Bartha S, Mika J, Dobi-Wantuch I, Rédei T, Rajkai K, Hahn I (2000) Changes in the composition of sand grasslands along a climatic gradient in Hungary and implications for climate change. Phytocoenologia 30:385-407

Kröel-Dulay G, Csecserits A, Szitár K, Molnár E, Szabó R, Ónodi G, Botta-Dukát Z (2019) The potential of common ragweed for further spread: invasibility of different habitats and the role of disturbances and propagule pressure. Biol Invasions 21:137149. https://doi.org/10.1007/s10530-018-1811-3

Kun A (2001) Analysis of precipitation year and their regional frequency distributions in the Danube-Tisza mid-region, Hungary. Acta Bot Hung 43:175-187. https://doi.org/10.1556/ abot.43.2001.1-2.10

Le Dantec V, Dufrêne E, Saugier B (2000) Interannual and spatial variation in maximum leaf area index of temperate deciduous stands. For Ecol Manag 134:71-81. https://doi.org/10.1016/ S0378-1127(99)00246-7

Leuschner C, Ellenberg H (2018) Ecology of Central European forests. Springer, Cham

Löf M, Gemmel P, Nilsson U, Welander NT (1998) The influence of site preparation on growth in Quercus robur L. seedlings in a southern Sweden clear-cut and shelterwood. For Ecol Manag 109:241-249. https://doi.org/10.1016/S0378-1127(98)00254-0

López-Sánchez A, Peláez M, Dirzo R, Fernandes GW, Seminatore M, Perea R (2019) Spatio-temporal variation of biotic and abiotic stress agents determines seedling survival in assisted oak regeneration. J Appl Ecol 56:2663-2674. https://doi. org/10.1111/1365-2664.13500

Lorimer CG, Chapman JW, Lambert WD (1994) Tall under-storey vegetation as a factor in the poor development of oak seedlings beneath mature stands. J Ecol 82:227-237. https://doi. org/10.2307/2261291

Matías L, Quero JL, Zamora R, Castro J (2012a) Evidence for plant traits driving specific drought resistance. A community field experiment. Environ Exp Bot 81:55-61. https://doi. org/10.1016/j.envexpbot.2012.03.002

Matías L, Zamora R, Castro J (2012b) Sporadic rainy events are more critical than increasing of droughtintensity for woody species recruitment in a Mediterranean community. Oecologia 169:833-844. https://doi.org/10.1007/s00442-011-2234-3

Mellert KH, Lenoir J, Winter S, Kölling C, Čarni A, Dorado-Liñán I, Gégout J-C, Göttlein A, Hornstein D, Jantsch M, Juvan N, Kolb E, López-Senespleda E, Menzel A, Stojanović D, Täger S, Tsiripidis I, Wohlgemuth T, Ewald J (2018) Soil water storage appears to compensate for climatic aridity at the xeric margin of European tree species distribution. Eur J For Res 137:79-92. https://doi.org/10.1007/s10342-017-1092-x
Mendoza I, Zamora R, Castro J (2009) A seeding experiment for testing tree-community recruitment under variable environments: implications for forest regeneration and conservation in Mediterranean habitats. Biol Conserv 142:1491-1499. https:// doi.org/10.1016/j.biocon.2009.02.018

Molnár Z, Biró M, Bartha S, Fekete G (2012) Past trends, present state and future prospects of Hungarian forest-steppes. In: Werger MJA, van Staalduinen MA (eds) Eurasian steppes: Ecological problems and livelihoods in a changing world. Springer, Dordrecht, pp 209-252

Neilson RP (1993) Transient ecotone response to climatic change: some conceptual and modelling approaches. Ecol Appl 3:385395. https://doi.org/10.2307/1941907

Nilsson U, Gemmel P, Löf M, Welander T (1996) Germination and early growth of sown Quercus robur L. in relation to soil preparation, sowing depths and prevention against predation. New For 12:69-86. https://doi.org/10.1007/BF00029983

Olrik DC, Hauser TP, Kjaer ED (2012) Natural colonisation of an open area by Quercus robur L.- from where did the vectors disperse the seed? Scand J For Res 27:350-360. https://doi. org/10.1080/02827581.2011.644318

Onaindia A, Gegout JC, Piedallu C, Nicolescu NV, Bastien Y (2001) Research on forest vegetation naturally regenerated on abandoned agricultural, vine growing, orchard and pasture lands in the Amance-Apance region (Haute-Marne County, France). Rev Padurilor 116:19-26

Peters DPC, Gosz JR, Pockman WT, Small EE, Parmenter RR, Collins SL, Muldavin E (2006) Integrating patch and boundary dynamics to understand and predict biotic transitions at multiple scales. Landsc Ecol 21:19-33. https://doi.org/10.1007/s1098 0-005-1063-3

Pfadenhauer JS, Klötzli FA (2014) Vegetation der Erde: Grundlagen, Ökologie, Verbreitung. Springer, Berlin

Pinheiro J, Bates D, DebRoy S, Sarkar D, R Core Team (2017) nlme: linear and nonlinear mixed effects models. $\mathrm{R}$ package version 3.1-131. https://CRAN.R-project.org/package=nlme. Accessed 2 June 2020

Pinto-Ledezma JN, Larkin DJ, Cavender-Bares J (2018) Patterns of beta diversity of vascular plants and their correspondence with biome boundaries across north America. Front Ecol Evol 6:194. https://doi.org/10.3389/fevo.2018.00194

Rédei T, Csecserits A, Lhotsky B, Barabás S, Kröel-Dulay G, Ónodi G, Botta-Dukát Z (2020) Plantation forests cannot support the richness of forest specialist plants in the forest-steppe zone. For Ecol Manag 461:117964. https://doi.org/10.1016/j.foreco.2020.117964

Reif A, Gärtner S (2007) Die natürliche Verjüngung der laubabwerfenden Eichenarten Stieleiche (Quercus robur L.) und Traubeneiche (Quercus petraea Liebl.): eine Literaturstudie mit besonderer Berücksichtigung der Waldweide. Waldökologie Online 5:79-116

Risser PG (1995) The status of the science examining ecotones. Bioscience 45:318-325. https://doi.org/10.2307/1312492

Rousset O, Lepart J (2000) Positive and negative interactions at different life stages of a colonizing species (Quercus humilis). J Ecol 88:401-412. https://doi.org/10.1046/j.1365-2745.2000.00457.x

Schäfer D, Prati D, Schall P, Ammer C, Fischer M (2019) Exclusion of large herbivores affects understorey shrub vegetation more than herb vegetation across 147 forest sites in three German regions. PLoS ONE 14:e0218741. https://doi.org/10.1371/journ al.pone. 0218741

Schultz J (2005) The ecozones of the world. Springer, Berlin

Shaw MW (1968a) Factors effecting the natural regeneration of sessile oak (Quercus petraea) in North-Wales: I. A preliminary study of acorn production, viability and losses. J Ecol 56:565-583. https ://doi.org/10.2307/2258251 
Shaw MW (1968b) Factors effecting the natural regeneration of sessile oak (Quercus petraea) in North-Wales: II. Acorn losses and germination under field conditions. J Ecol 56:647-660. https:// doi.org/10.2307/2258097

Soudani K, François C, le Maire G, Le Dantec V, Dufrêne E (2006) Comparative analysis of IKONOS, SPOT, and ETM + data for leaf area index estimation in temperate coniferous and deciduous forest stands. Remote Sens Environ 102:161-175. https://doi. org/10.1016/j.rse.2006.02.004

Svenning J-C (2002) A review of natural vegetation openness in north-western Europe. Biol Conserv 104:133-148. https://doi. org/10.1016/S0006-3207(01)00162-8

Szabó P (2009) Open woodland in Europe in the Mesolithic and in the middle ages: can there be a connection? For Ecol Manag 257:2327-2330. https://doi.org/10.1016/j.foreco.2009.03.035

R Core Team (2017) R: a language and environment for statistical computing. R Foundation for Statistical Computing, Vienna. https ://www.R-project.org/. Accessed 2 June 2020

Thimonier A, Sedivy I, Schleppi P (2010) Estimating leaf area index in different types of mature forest stands in Switzerland: a comparison of methods. Eur J For Res 129:543-562. https://doi. org/10.1007/s10342-009-0353-8

Tölgyesi C, Török P, Hábenczyus AA, Bátori Z, Valkó O, Deák B, Tóthmérész B, Erdős L, Kelemen A (2020) Underground deserts below fertility islands? Woody species desiccate lower soil layers in sandy drylands. Ecography 43:848-859. https://doi. org/10.1111/ecog.04906

Urli M, Lamy J-B, Sin F, Burlett R, Delzon S, Porté AJ (2015) The high vulnerability of Quercus robur to drought at its southern margin paves the way for Quercus ilex. Plant Ecol 216:177-187. https:// doi.org/10.1007/s11258-014-0426-8

van Hees AFM (1997) Growth and morphology of pedunculate oak (Quercus robur L.) and beech (Fagus sylvatica L.) seedlings in relation to shading and drought. Ann For Sci 54:9-18. https://doi. org/10.1051/forest: 19970102

Van Uytvanck J, Maes D, Vandenhaute D, Hoffmann M (2008) Restoration of woodpasture on former agricultural land: the importance of safe sites and time gaps before grazing for tree seedlings. Biol Conserv 141:78-88. https://doi.org/10.1016/j.biocon.2007.09.001
Vander Wall SB (2001) The evolutionary ecology of nut dispersal. Bot Rev 67:74-117. https://doi.org/10.1007/BF02857850

Várallyay G (1993) Soils in the region between the Rivers Danube and Tisza (Hungary). In: Szujkó-Lacza J, Kováts D (eds) The flora of the Kiskunság National Park. Hungarian Natural History Museum, Budapest, pp 21-42

Vera FWM (2000) Grazing ecology and forest history. CABI Publishing, Wallingford

Von Lüpke B, Hauskeller-Bullerjahn K (2004) Beitrag zur Modellierung der Jungwuchsentwicklung am Beispiel von Traubeneichen-Buchen-Mischverjüngungen. Allgemeine Forst- und Jagdzeitung 175:61-69

Walter H (1985) Vegetation of the earth and ecological systems of the geo-biosphere, 3rd edn. Springer, Berlin

Walter H, Breckle S-W (1989) Ecological systems of the geobiosphere 3. Springer, Berlin

Welander NT, Ottosson B (1998) The influence of shading on growth and morphology in seedlings of Quercus robur L. and Fagus sylvatica L. For Ecol Manag 107:117-126. https://doi.org/10.1016/ S0378-1127(97)00326-5

Wesche K, Ambarlı D, Kamp J, Török P, Treiber J, Dengler J (2016) The Palaearctic steppe biome: a new synthesis. Biodivers Conserv 25:2197-2231. https://doi.org/10.1007/s10531-016-1214-7

Ziegenhagen B, Kausch W (1995) Productivity of young shaded oaks (Quercus robur L.) as corresponding to shoot morphology and leaf anatomy. For Ecol Manag 72:97-108. https://doi. org/10.1016/0378-1127(94)03482-C

Ziobro J, Koziarz M, Havrylyuk S, Korol M, Ortyl B, Wolański P, Bobiec A (2016) Spring grass burning: an alleged driver of successful oak regeneration in sub-carpathian marginal woods. A case study. Prace Geograficzne 146:67-88

Publisher's Note Springer Nature remains neutral with regard to jurisdictional claims in published maps and institutional affiliations. 